\title{
Prevalence and Antibiotic Susceptibility of Bacterial Pathogens in Children with Acute Otitis Media - A Retrospective Study at Tertiary care Teaching
} Hospital, India

\author{
Dr. Chandrakala Penagadam ${ }^{1 *}$, Y. Dhanush Chandra Yadav ${ }^{2}$, Dr. Ch. Srinivasarao
}

\author{
${ }^{1}$ Assistant Professor, Department of Microbiology, S.V. Medical College, Tirupati, India-517507 \\ ${ }^{2}$ Enginnering Undergraduate, Department of Electrical Engineering, Blekinge Institute of Technology, Sweden-37141 \\ ${ }^{3}$ Professor \& HOD, Department of Microbiology, S.V. Medical College, Tirupati, India-517507
}

DOI: $10.36347 /$ sajp.2021.v10i04.004

| Received: 09.03.2021 | Accepted: 14.04.2021 | Published: 18.04.2021

*Corresponding author: Dr. Chandrakala Penagadam

Abstract

Original Research Article

Aim: To demonstrate the prevalence of bacterial pathogens and it's antibiotic sensitivity in children (0-18years) with acute otitis media (AOM) at tertiary care teaching hospital. Materials and Methods: This is a retrospective study of 108 patient's ear discharge samples with acute otitis media at department of Microbiology, Sri Venkateswara Medical College, during the period January 2018 to December 2018. The specimens / swabs were cultured using aerobic microbiological techniques and Antimicrobial susceptibility pattern to different agents was carried out with the disc diffusion method according to the criteria of the Clinical and Laboratory Standards Institute (CLSI). Results: Cultures from AOM samples/swabs revealed Staphylococcus aureus (58) was the most frequently identified pathogen in children below 6 years. Out of 58, 12 isolates were Methicillin resistant Staphylococcus aureus (MRSA). Pseudomonas aeruginosae was the second most frequently identified pathogen. In our study, most of the Staphylococcus aureus were resistant to Penicillins and first generation cephalosporins; Pseudomonas aeruginosae to fluoroquinolones. Conclusion: The study also reveals that there are differences in the pathogens isolated and their antibacterial susceptibility patterns from different regions. Hence, it is the need of the hour to have a study at the regional level to know the common pathogens causing acute otitis media (AOM) and their susceptibility pattern for an efficient treatment, prevention of both complications and development of antibiotic resistance and finally, the reduction of the treatment costs.

Keywords: Acute Otitis Media (AOM), Infection, Common Pathogens, Antibiotic Susceptibility.

Copyright ( () 2021 The Author(s): This is an open-access article distributed under the terms of the Creative Commons Attribution 4.0 International License (CC BY-NC 4.0) which permits unrestricted use, distribution, and reproduction in any medium for non-commercial use provided the original author and source are credited

\section{INTRODUCTION}

Acute otitis media (AOM) one of the most common infections in children aged $<5$ years. Otitis media $(\mathrm{OM})$ is defined as inflammation of middle ear that may present with recurrent ear discharge or otorrhoea through tympanic membrane perforation. The three criteria for Acute Otitis Media (AOM) include acute onset of symptoms (fever, irritability, and earache), signs of inflammation of the tympanic membrane (TM), and presence of Middle ear effusion [1].

The cumulative worldwide AOM incidence rate is $10.85 \%$, which is about 709 million cases per year, out of which $51 \%$ occur in children aged $<5$ years [2]. Approximately $80 \%$ of children are affected by AOM during their first 5 years of life; the incidence rate is higher in males than females [3]. Estimates for 2005 suggest that the incidence rates of AOM in South Asia and North Africa (Middle East regions) were 14.52\% and $8.67 \%$, respectively [2]. The disease burden is greatest between 6 months and 18 months of age and if left untreated, may lead to permanent hearing loss [4]. Furthermore, recurrent AOM episodes may lead to chronic suppurative otitis media potentially resulting in severe complications, such as intracranial infection, hearing impairment and facial paralysis $[5,6]$.

The most common bacterial pathogens in $\mathrm{OM}$ are Streptococcus pneumoniae, Hemophilus influenzae, and Moraxella catarrhalis [7, 8]. Globally, the major bacterial pathogens responsible for AOM are Streptococcus pneumoniae, Haemophilus influenzae and to a lesser extent, Moraxella catarrhalis, S. pyogenes and Staphylococcus aureus [9]. Literature 
Chandrakala Penagadam et al., Sch Acad J Pharm, Apr, 2021; 10(4): 77-81

reported that the geographical area and respiratory infections may affect the type of OM pathogens. In an Iranian study, the most frequently isolated microorganisms have been Staphylococcus aureus, Pseudomonas aeruginosa, and Proteus sp. [10]. Little is known about microbial epidemiology of AOM in India.

The growing bacterial resistance to antibiotics has altered the clinical picture of otitis media and its complications. The emergence of Multi Drug Resistance (MDR) is clearly related to the dose of antibiotics and how they are being used [11]. Serious infections caused by methicillin-resistant S. aureus (MRSA) are increasingly difficult to treat. While it is clear that antibiotics are pivotal in the selection of bacterial resistance, the spread of resistance genes and resistant bacteria also contributes to the problem [12]. Most of the time treatment for OM is done clinically, especially in health facilities found in low income countries. This will cause bacterial drug resistance and preventable complications of OM such as deafness and meningitis [13].

Commonly prescribed antimicrobials for the treatment of OM infection include penicillin, cephalosporins, vancomycin, and macrolides (clarithromycin and azithromycin) [14]. Pathogens that cause acute $\mathrm{OM}$ to become resistant to commonly used antibiotics [15-17]. The increasing rates of antibiotic resistance are due to repeated exposure to these bacteria to antibiotics and the geographic spread of resistant strains [18]. The rapid emergence of multidrug-resistant $\mathrm{OM}$ in developing countries is a new potential threat to the survival of newborn babies and children [19].

Hence, the periodic update of prevalence and antibiotic susceptibility of the etiological agents would be helpful in therapy and management of patients with otitis media.

\section{AIM}

To demonstrate the prevalence of bacterial pathogens and its antibiotic susceptibility in children with acute otitis media (AOM) at tertiary care teaching hospital.

\section{OBJECTIVES}

1. To demonstrate the prevalence of bacterial pathogens in children with acute otitis media (AOM) at SVRRGG hospital, SV Medical College, Tirupati, Andhrapradesh, India.

2. Identification and characterization of the aerobic pathogens and their antibiotic susceptibility pattern.

\section{MATERIALS AND METHODS}

A retrospective study was carried out on 108 specimens with Acute Otitis Media (AOM) in children during the period January 2018 to December 2018 at Department of Microbiology, Sri Venkateswara Medical College, Tirupati, Andhrapradesh, India. A semi-structured questionnaire was prepared to record the medical history, examination details and investigation reports from Medical Record Section at S.V.R.R.G. General Hospital, Tirupati, Andhrapradesh. Specimens/Swabs were inoculated on Blood agar, MacConkey agar, Chocolate agar and Nutrient agar (Himedia Laboratories Pvt Ltd., Mumbai). After overnight incubation, the plates were examined for bacterial growth. Further identification and confirmation of organisms was done by the standard identification techniques, which include studying the colonial morphology, Gram's stain and Biochemical reactions.

\section{Antibiotic Susceptibility Testing}

Susceptibility testing was performed by KirbyBauer disk diffusion technique according to criteria set by CLSI. The drugs tested for aerobic pathogens were Penicillin, Ampicillin, Amoxyclav, Cephalexin, Cefuroxime, Cefotaxime, Ceftazidime, Co-trimoxazole, Piperacillin/ Tazobazctam, Gentamicin, Amikacin, Ofloxacin, Ciprofloxacin, Levofloxacin, Erythromycin and Clindamycin.

The exclusion criteria were: (i) Use of antibiotics within the past 3 months; (ii) had an invasive medical intervention within the past 3 months; (iii) had a past history of any cancer, or inflammatory disease.

\section{Stastical Analysis}

All the study data were enterd into the computer database using standard format, checked for errors and verified. Data maintained in the computer sheets were organised by SPSS version 17.0 software for Windows. Data will be peresented in apropriate Tables by caliculating of percentage, rate etc.

\section{Ethical Issues}

The retrospective study was approved and ethically cleared by the Scientific Committee of Sri Venkateswara Medical College, Tirupati. All patient information was kept confidential.

\section{RESULTS AND DISCUSSION}

A total number of 108 acute otitis media (AOM) cases samples were included in this retrospective study between January 2018 to December 2018. The ages of study groups ranged from 0 yrs to 18 yrs. This study was done to know the bacterial pathogens and its antibiotic susceptibility in children with acute otitis media. The results are compared and correlated with the studies conducted by other researchers. 
Chandrakala Penagadam et al., Sch Acad J Pharm, Apr, 2021; 10(4): 77-81

\begin{tabular}{|c|c|c|c|c|}
\hline & $\begin{array}{l}\text { Children } \\
(0-06 \text { years })\end{array}$ & $\begin{array}{l}\text { Children } \\
(06-12 \text { years })\end{array}$ & $\begin{array}{l}\text { Children } \\
(12-18 \text { years })\end{array}$ & Total \\
\hline Number & 58 & 30 & 20 & 108 \\
\hline Percentage & $53.7 \%$ & $27.78 \%$ & $18.52 \%$ & $100 \%$ \\
\hline
\end{tabular}

The occurrence of the ASOM in children as follows: $58(53.7 \%)$ were < 6 years of age, $30(27.78 \%)$ were $06-12$ years of age and $20(18.52 \%)$ were $12-$
18 years of age. Children <6 years of age was found to be higher compared to other age group children Table1 .

Table-2: Overall results of the cases studied

\begin{tabular}{|l|l|l|}
\hline Details of Isolation & Number & Percentage \\
\hline Monomicrobial & 36 & $33.33 \%$ \\
\hline Polymicrobial & 72 & $66.67 \%$ \\
\hline Total & 108 & $100 \%$ \\
\hline
\end{tabular}

Of the 108 swabs $36 \quad(33.33 \%)$ were monomicrobial pathogens and $72(66.67 \%)$ were Polymicrobial pathogens. The presence of more than one species isolated from 72 samples was the most frequent $(66.67 \%)$ while, one species were isolated $(33.33 \%)$ from 36 samples.

Table-3: Aerobic bacterial pathogens isolated from AOM cases

Total Number of Specimens - 108

Total Number of Isolates - 128

\begin{tabular}{|l|l|l|}
\hline Organisms & Number of Isolates & Percent Among the Isolates \\
\hline Staphylococcus aureus & 58 & $45.31 \%$ \\
\hline Pneumococci & 15 & $11.72 \%$ \\
\hline Citrobacter freundii & 4 & $3.13 \%$ \\
\hline Klebsiella pneumoniae & 9 & $7.03 \%$ \\
\hline Escherichia coli & 4 & $3.13 \%$ \\
\hline Moraxella catarrhalis & 2 & $1.7 \%$ \\
\hline Proteus mirabilis & 2 & $1.7 \%$ \\
\hline Pseudomonas spp. & 34 & $26.56 \%$ \\
\hline
\end{tabular}

A total of 128 bacterial isolates were obtained, $73(57.03 \%)$ were aerobic Gram positive cocci. While $55(42.97 \%)$ were aerobic Gram negative bacilli. Staphylococcus aureus was the predominant organism isolated $58(45.31 \%)$. Pseudomonas aeruginosae was the predominant Gram negative bacilli isolated 34 $(26.56 \%)$, followed by Pneumococci 15 (11.72\%) Table-3.

Table-4: Antibiotic sensitivity pattern of Pathogens isolated in the study population.

\begin{tabular}{|c|c|c|c|c|c|c|c|c|c|c|c|c|c|c|c|c|c|}
\hline 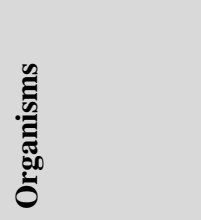 & 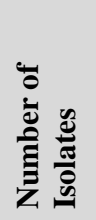 & 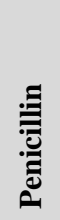 & 哥 & 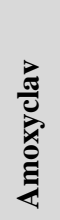 & 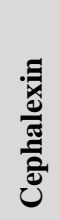 & 莣 & 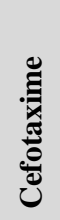 & 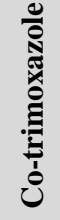 & 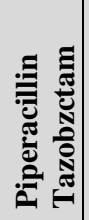 & 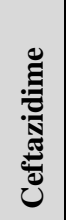 & 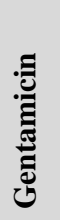 & 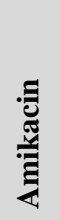 & 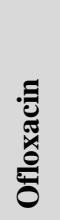 & 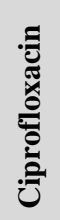 & 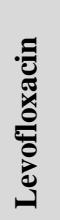 & 预 & 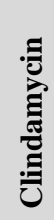 \\
\hline S. aureus & 58 & 12 & 11 & 21 & 18 & 21 & 23 & 18 & - & - & 21 & 24 & 28 & 16 & 24 & 15 & 23 \\
\hline P. aeruginosae & 34 & - & - & - & - & - & - & 12 & 32 & 22 & 18 & 26 & 12 & 6 & 14 & - & - \\
\hline Pneumococci & 15 & 15 & 15 & - & - & - & - & - & - & - & - & - & 15 & - & - & 15 & 14 \\
\hline $\begin{array}{l}\text { K. } \\
\text { pneumoniae }\end{array}$ & 09 & - & 06 & - & - & - & - & - & 08 & 09 & 09 & - & 09 & 05 & 06 & - & 07 \\
\hline
\end{tabular}

Table-4.

Antibiotic susceptibility testing was done and the sensitivity pattern of the four common isolates is shown in 
Chandrakala Penagadam et al., Sch Acad J Pharm, Apr, 2021; 10(4): 77-81

Table-5: Distribution of Pathogens isolated in various other studies in Otitis media

\begin{tabular}{|c|c|c|c|c|c|c|c|c|c|c|}
\hline Organisms & $\begin{array}{l}\begin{array}{l}\text { Present } \\
\text { study }\end{array} \\
\end{array}$ & Uttarkhand $^{2}$ & Bombay $^{20}$ & Pondichery ${ }^{22}$ & Nigeria $^{29}$ & Germany $^{24}$ & Japan $^{25}$ & $\mathrm{USA}^{26}$ & Bulgeria $^{27}$ & Finnish $^{28}$ \\
\hline S. aureus & $45.31 \%$ & $48.6 \%$ & $26.6 \%$ & $19 \%$ & $4.92 \%$ & - & - & - & - & - \\
\hline P. aeruginosae & $26.56 \%$ & $38 \%$ & $28.3 \%$ & $32 \%$ & $57.4 \%$ & - & - & - & - & - \\
\hline Pneumococci & $11.72 \%$ & $1.05 \%$ & - & - & $3.28 \%$ & $10 \%$ & $25 \%$ & - & $47.6 \%$ & $26 \%$ \\
\hline K. pneumonia & $7.03 \%$ & $18 \%$ & - & - & $16.4 \%$ & - & - & - & - & - \\
\hline $\begin{array}{l}\text { Citrobacter } \\
\text { freundii }\end{array}$ & $3.13 \%$ & - & - & - & $18 \%$ & - & - & - & - & - \\
\hline $\begin{array}{l}\text { Escherichia } \\
\text { coli }\end{array}$ & $3.13 \%$ & $14 \%$ & - & - & $3.28 \%$ & & & & & \\
\hline $\begin{array}{l}\text { Moraxella } \\
\text { catarrhalis }\end{array}$ & $1.7 \%$ & - & - & - & - & $1 \%$ & $20 \%$ & - & - & $23 \%$ \\
\hline $\begin{array}{l}\text { Proteus } \\
\text { mirabilis }\end{array}$ & $1.7 \%$ & - & - & $20 \%$ & $11.5 \%$ & - & - & - & - & - \\
\hline
\end{tabular}

\section{DISCUSSION}

In this retrospective study, Staphylococcus aureus was the most frequently identified pathogen in children less than $18 \mathrm{yr}$ and was also frequently identified in below 6 years. Out of 58, 12 isolates were Methicillin resistant Staphylococcus aureus (MRSA). Pseudomonas aeruginosae was the second most frequently identified pathogen. These results are consistent with the studies conducted in other parts of India [20-22].

In a large evaluation of Acute Otitis Media (AOM) etiology conducted in Israel, S. pyogenes AOM was observed more frequently in older children than in younger children, and was often associated with acute tympanic membrane perforation [23]. The high rate of Staphylococcus aureus isolation from AOM samples in the present study supports that the Staphylococcus aureus infection rapidly leads to Tympanic membrane perforation and likely reflects the severity of disease. Compared to studies conducted in developed countries [24-28], where the most common isolates are Streptococcus pyogens and Haemophillus influenzae, developing and underdeveloped countries like India [20-22], and Nigeria [29], shows S.aureus and P.aeruginosae are more commonly seen (Table-5). In India due to over-crowding, poor hygiene, malnutrition and inadequate healthcare the incidence of perforated tympanic membrane caused by otitis media is reported more when compared to developed countries.

In our study, most of the Staphylococcus aureus were resistant to Penicillins and first generation cephalosporins; Pseudomonas aeruginosae to fluoroquinolones. It may be due to inappropriate use and over use of antibacterial eardrops. As these antibacterial ear drops are easily available over the counter, these are misused in the rural population also. The study reveals reduced susceptibility of the pathogens isolated to first and second line antibiotics in rural settings. Hence, it is necessary to use these antibiotics judiciously and in the right dosage.

The study also reveals that there are differences in the pathogens isolated and their antibacterial susceptibility patterns from different regions. Hence, it is the need of the hour to have a study at the regional level to know the common pathogens causing Acute otitis Media (AOM) and their susceptibility pattern for easy administration of appropriate antibiotics.

Competing Interests: The author(s) declare that they have no competing interests.

\section{ACKNOWLEDGEMENTS}

We acknowledge the cooperation rendered by the staffs of the Microbiology department of Sri Venkateswara Medical College; Medical Record Section - teaching hospital includes, S.V.R.R. Government General Hospital, Tirupati and Engineering undergraduate student from BTH, Sweden.

\section{REFERENCES}

1. Subcommittee on Management of Acute Otitis Media. American Academy of Pediatrics and American Academy of Family Physicians. Clinical Practice Guideline: Diagnosis and management of acute otitis media. Pediatrics. 2004; 113: 1451-1465. [PubMed: 15121972]

2. Monasta L, Ronfani L, Marchetti F, Montico M, Brumatti LV, Bavcar A, Grasso D, Barbiero C, Tamburlini G. Burden of disease caused by otitis media: systematic review and global estimates. PloS one. 2012 Apr 30;7(4):e36226.

3. Klein JO. Otitis media. Clin Infect Dis. 1994; 19(5):823-33.

4. Klein JO. The burden of otitis media. December 2000 Vaccine 19 Suppl 1(Suppl 1):S2-8.

5. Rovers MM, Schilder AG, Zielhuis GA, Rosenfeld RM. Otitis media. Lancet. 2004;363(9407):465-73.

6. Vergison A, Dagan R, Arguedas A, Bonhoeffer J, Cohen R, Dhooge I, et al. Otitis media and its consequences: beyond the earache. Lancet Infect Dis. 2010;10(3):195-203.

7. Kilpi T, Herva E, Kaijalainen T, Syrjanen R, Takala AK. Bacteriology of acute otitis media in a cohort of Finnish children followed for the first two years of life. Pediatr Infect Dis J. 2001 Jul;20(7):654-62. 
8. Block SL. Causative pathogens, antibiotic resistance and therapeutic considerations in acute otitis media. Pediatr Infect Dis J. 1997 Apr;16(4):449-56.

9. Leibovitz E, Jacobs MR, Dagan R. Haemophilus influenzae: a significant pathogen in acute otitis media. Pediatr Infect Dis J. 2004, 23: 1142-1152.

10. Ettehad GH, Refahi S, Nemmati A, Pirzadeh A, Daryani A. Microbial and Antimicrobial Susceptibility Patterns from patients with chronic otitis media in Ardebil. Int $\mathbf{J}$ Trop Med. 2006;1(2):62-5.

11. Ahmad S. Antibiotics in chronic suppurative otitis media: a bacteriologic study. Egypt J Ear Nose Throat Allied Sci. 2013;14(3):191-4.

12. Levy SB. Factors impacting on the problem of antibiotic resistance. J Antimicrob Chemother. 2002;49(1):25-30.

13. Mohammed S, Al-Kadassy A, Bashanfer S, Moad AI. Bacterial isolates from otitis media infections and their Antibiograms, Hodeidah City, Yemen. Brit Microbiol Res J. 2016;13(1):1.

14. Poole MD. Otitis media complications and treatment failures: implications of pneumococcal resistance. Pediatr Infect Dis J. 1995 Apr;14(4):S23-6.

15. van Kempen MJ, Vaneechoutte M, Claeys G, Verschraegen GL, Vermeiren J, Dhooge IJ. Antibiotic susceptibility of acute otitis media pathogens in otitis prone Belgian children. Eur J Pediatr. 2004 Sep;163(9):524-9.

16. Osazuwa F, Osazuwa E, Osime C, Igharo EA, Imade $\mathrm{PE}$, Lofor P, et al. Etiologic agents of otitis media in Benin city, Nigeria. N Am J Med Sci. 2011 Feb;3(2):95-8.

17. Friedland IR, McCracken GH Jr. Management of infections caused by antibiotic-resistant Streptococcus pneumoniae. N Engl J Med. 1994 Aug;331(6):377-82.

18. Falagas ME, Mourtzoukou EG, Vardakas KZ. Sex differences in the incidence and severity of respiratory tract infections. Respir Med. 2007;101(9):1845-63.

19. Jacobs MR, Dagan R, Appelbaum PC, Burch DJ. Prevalence of antimicrobial resistant pathogens in middle ear fluid: multinational study of 917 children with acute otitis media. Antimicrob Agents Chemother. 1998 Mar;42(3):589-95.

20. Prakash R, Juyal D, Negi V, Pal S, Adekhandi S, Sharma M, Sharma N. Microbiology of Chronic Suppurative Otitis Media in a Tertiary Care Setup of
Uttarakhand State, India. N Am J Med Sci. 2013 April; 5(4): 282-287

21. De A, Varaiya A, Tainwala S, Mathur M. Bacteriology of acute otitis media in children. Indian J Med Microbiol [serial online] 2002 [cited 2013 Jul 21]; 20: 54-5.

22. Madana J, Yolmo D, Kalaiarasi R, Gopalakrishnan S, Sujatha S. Microbiological profile with antibiotic sensitivity pattern of cholesteatomatous chronic suppurative otitis media among children. Int J Pediatr Otorhinolaryngol. 2011 Sep; 75(9): 1104-8.

23. Segal N, Givon-Lavi N, Leibovitz E, Yagupsky P, Leiberman A, Dagan R. Acute otitis media caused by Streptococcus pyogens in children. Clin Infect Dis. 2005, 41: 35-41.

24. Grevers G, Wiedemann S, Bohn JC, Blasius RW, Harder T, Kroeniger W, Vetter V, Pirçon JY, Marano C. Identification and characterization of the bacterial etiology of clinically problematic acute otitis media after tympanocentesis or spontaneous otorrhea in German children. BMC infectious diseases. 2012 Dec;12(1):1-5.

25. Yamanaka N, Hotomi M, Billal DS. Clinical bacteriology and immunology in acute otitis media in children. Journal of Infection and Chemotherapy. 2008 Jan 1;14(3):180-7.

26. Holder RC, Kirse DJ, Evans AK, Peters TR, Poehling KA, Swords W, Reid SD. One third of middle ear effusions from children undergoing tympanostomy tube placement had multiple bacterial pathogens. BMC Pediatrics. 2012, 12: 87.

27. Setchanova LP, Kostyanev $\mathrm{T}$, Alexandrova AB, Mitov IG, Nashev D, Kantardjiev T. Microbiological characterization of Streptococcus pneumoniae and non-typable Haemophilus influenzae isolates as primary causes of acute otitis media in Bulgarian children before the introduction of conjugate vaccines. Annals of Clinical Microbiology and Antimicrobials. 2013, 12: 6.

28. Ruohola A, Meurman O, Nikkari S, Skottman T, Salmi A, Waris M, Österback R, Eerola E, Allander T, Niesters H, Heikkinen T. Microbiology of acute otitis media in children with tympanostomy tubes: prevalences of bacteria and viruses. Clinical Infectious Diseases. 2006 Dec 1;43(11):1417-22.

29. Nnebe-Agumadu U, Okike O, Orji I, Ibekwe RC. Childhood suppurative otitis media in Abakaliki: Isolated microbes and in vitro antibiotic sensitivity pattern. Niger J Clin Pract. 2011; 14: 159-62. 